DE DE GRUYTER

OPEN

DOI 10.2478/pesd-2014-0011

PESD, VOL. 8, no. 1, 2014

\title{
ENDOSULFAN RESISTANCE PROFILE OF SOIL BACTERIA AND POTENTIAL APPLICATION OF RESISTANT STRAINS IN BIOREMEDIATION
}

\author{
Chandini P.K ${ }^{1}$, Jaysooryan K.K ${ }^{1}$, Rinoy $\operatorname{Varghese}^{1}$ Sreedharan K. $^{1}$, \\ K. P. Smitha ${ }^{2}$
}

Key-words: Soil, pesticide, endosulfan, socio-economic impacts, bacterial resistance, Bioremediation

\begin{abstract}
In the present study, bacterial strains were isolated from the soils of Wayanad District, Kerala, India and the isolates were tested for their tolerance to endosulfan and potential in bioremediation technology. Pesticide contamination in the soils, soil physico-chemical characteristics and socio-economic impacts of pesticide application were also analyzed. 28 pesticide compounds in the soil samples were analyzed and the results revealed that there was no pesticide residues in the soils. As per the survey conducted the pesticide application is very high in the study area and the level of awareness among the farmers was very poor regarding the method of application and its socio-economic and ecological impacts. A total of 9 bacterial strains were isolated with $50 \mu \mathrm{g} / \mathrm{ml}$ of endosulfan in the isolating media and the results showed that most of the bacterial strains were highly resistance to endosulfan. Out of the 9 strains isolated 6 were highly resistant to endosulfan (500$700 \mu \mathrm{g} / \mathrm{ml}$ ) and the other 3 isolates showed the resistance of $250-500 \mu \mathrm{g} / \mathrm{ml}$. From the studied isolate, isolate 9 demonstrating prolific growth and high resistance was selected to check their capability to degrade endosulfan over time. Identification of the selected strain reveals that it belongs to the genus Bacillus. Results of endosulfan removal studies showed that with increase in time, the biomass of the bacterial strains increased. The complete disappearance of endosulfan from the spiked and inoculated broth during the first day of incubation ( 24 hour interval) was observed. While the control flask showed the presence of endosulfan during the experimental period. Pesticide resistant bacteria are widely distributed in the soils of selected study area and the tolerance varied between bacteria even though they were isolated
\end{abstract}

\footnotetext{
${ }^{1}$ School of Environmental Sciences, Mahatma Gandhi University, Kottayam, Kerala, India. renochirackal@gmail.com

${ }^{2}$ M S Swaminathan Research Foundation, Community Agrobiodiversity Centre, Kalpetta Wayanad, Kerala, India.
} 
from the soils of the same area. The selected Bacillus species carry the ability to degrade endosulfan at accelerated rates and it could be useful in framing a bioremediation strategy for pesticide contaminated soil and water environments.

\section{Introduction}

Plants on which we depend for food are under attack from insects, fungi, bacteria, viruses, rodents and other animals, and must compete with weeds for nutrients. To destroy unwanted populations living in or on their crops, farmers use pesticides. The first widespread insecticide use began at the end of World War II and included DDT (dichlorodiphenyltrichloroethane) and gammaxene. Insects soon became resistant to DDT and as the chemical did not decompose readily, it persisted in the environment. Since it was soluble in fat rather than water, it also biomagnified up the food chain. The most important pesticides are DDT, BHC, chlorinated hydrocarbons, organophosphates, aldrin, malathion, dieldrin, furdan etc. The remnants of such pesticides used on pests may get adsorbed by the soil particles, which then contaminate crops grown in that soil. The consumption of such crops causes the pesticides remnants to enter human biological systems, affecting them adversely. Pesticides not only bring toxic effect on human and animals but also decrease the fertility of the soil. Some of the pesticides are quite stable and their bio-degradation may take weeks and even months.

Endosulfan (6,7,8,9,10,10-hexachloro-1,5,5a,6,9,9a-hexahydro-6,9-methano2,3,4-benzo(e) dioxathiepin-3-oxide) is a chlorinated compound, widely employed as pesticide in world farming. Technical preparation of endosulfan consists of aand b-isomers (70:30). Endosulfan contamination has been detected in soils, water, air and foods because of its profuse practice and possible for environmental transport. It is extremely toxic to fishes and aquatic invertebrates (Verschueren, 1983; Sunderam et al. 1992) and is classified as a priority pollutant by international environmental agencies (Keith and Telliard, 1979). The persistence of endosulfan in agricultural soils has been studied in many laboratories. Its life in soils has been estimated to be from 100 to 120 days (Rao and Murty 1980; Kathpal et al. 1997) to several months (Stewart and Cairns 1974).

Accessibility of different pesticides in field provides contact of several different kinds of microorganisms to pesticides. Majority of them die under lethal effect of pesticides but only some of them advance in different ways and utilize pesticide compounds in metabolism. Numerous studies are available indicating degradation of different pesticides (Hussain et al. 2007; Lakshmi et. al. 2009). Successful removal of pesticides by the addition of bacteria had been reported earlier for many compounds, including chlorpyrifos, endosulfan, parathion, coumaphos, ethoprop, and atrazine (Singh et. al. 2004). Therefore in the present study aims to evaluate the endosulfan resistance profile of the bacterial isolates and 
bioremediation potential of highly resistant isolate. Pesticide contamination in the soils and socio-economic impacts of pesticide application were also analysed.

\section{Materials and methods}

1.1 Study Area: Wayanad, the agro based district of Kerala, South India is noted for its natural beauty, pleasant climate and the fertile soil. As the farmers of this area primarily depend on agriculture for their living, there is a necessity for the proper control of pests to make the cultivation economically a success. Reports say that the unscientific and indiscriminate use of pesticides by the farmers in this region has caused severe environmental pollution. Most of the paddy fields are extensively converted to banana plantations and extensively use inorganic fertilizers and pesticides. For the present study we selected banana and paddy fields of Padinjarathara and Kottathara Panchayaths of Wayanad district, Kerala, India.

1.2 Socio-economic and health impact survey: Wayanad being a zero industrial zone totally depended on agriculture for income. The present survey was conducted to get an idea on the consumption and use of fertilizers and pesticides in their crops and to what extent they are affected by its use. Interview method was used for the Socio-economic survey. The list of banana cultivators and rice cultivators were collected from the respective Agricultural department. Random sampling was done to select 62 farmers from the selected Panchayats. In view of the objectives a structural questioner was developed for collecting information.

1.3 Soil sampling: Soil samples were collected at a depth of 15 to $20 \mathrm{~cm}$ from the surface. For each of the sampling sites, 30 sub-samples of soil were collected from different locations, pooled together and homogenized so as to obtain representative sample. Samples were collected using a spade that is thoroughly cleaned and disinfected between sampling so as to prevent cross-contamination. Soil samples were packed in sterilized polythene bags and transferred to an ice box and transported to the laboratory.

1.4 Physicochemical characteristics of soil: Temperature was determined in situ with the help of mercury bulb thermometer. Soil moisture content was determined by gravimetric method. $\mathrm{pH}$ of soil samples were determined potentiometrically using $\mathrm{pH}$ meter. Available nitrogen in the soil samples was determined by Microkjeldahl method and the available phosphorus by Bray and Kurtz method (Jackson 1973). The available potassium was extracted using neutral normal ammonium acetate as extractant and determined by using flame photometer (Morgan 1941). The organic carbon was determined by Walkey and Black Method (Jackson 1973). Conductivity of the soil samples was determined by conductivity meter. Soil moisture content was measured by gravimetric method. 
1.5 Pesticide analysis: The soil samples were extracted and analyzed using Gas chromatographic techniques (Shimadzu) coupled to an Electron capture detector.

1.6 Isolation enumeration and identification total heterotrophic bacteria: Isolation of bacteria was carried out by standard serial dilution plate technique. 10 $\mathrm{g}$ of soil samples were transferred into $90 \mathrm{ml}$ sterile distilled water and agitated vigorously. Serially diluted samples were sow in Nutrient Agar supplemented with $50 \mu \mathrm{g} / \mathrm{ml}$ of endosulfan and incubated at $37^{\circ} \mathrm{C}$ for $24-48$ hours. After incubation, morphologically distinct colonies were picked and purified. Pure cultures of bacterial colonies were prepared and persevered as slant cultures for further analysis. The bacterial isolate exhibiting maximum resistance against endosulfan was identified by standard protocol (Holt et al. 1994).

1.7 Endosulfan resistance test: Resistance of the bacterial isolates to varying concentrations of endosulfan was determined by agar dilution method (Luli et al. 1983). Fresh overnight cultures of the isolates grown in peptone water were aseptically inoculated into nutrient agar plates, which were supplemented with increasing concentration of the endosulfan $(100 \mu \mathrm{g} / \mathrm{ml}$ to $800 \mu \mathrm{g} / \mathrm{ml})$. The plates were incubated at room temperature and observed for bacterial growth. The lowest concentration of pesticide at which no growth occurred was considered as the Minimal Inhibitory Concentration (MIC). Endosulfan was added to the medium after autoclaving and cooling to $45-50^{\circ} \mathrm{C}$, from filter sterilized stock solutions.

1.8 Bioremediation of endosulfan: The isolate (isolate 9) demonstrating prolific growth was investigated for their capability to degrade endosulfan over time. Endosulfan technical preparation consists of a- and b-isomers (70:30) was used for removal studies. For this purpose, $100 \mathrm{ml}$ of autoclaved medium (Nutrient agar) were put into $250 \mathrm{ml}$ flask. These flasks were spiked with endosulfan already dissolved in acetone to attain a final concentration of $100 \mu \mathrm{g} / \mathrm{ml}$ in a laminar flow hood for 10 minutes to allow acetone to evaporate. The flasks were inoculated with $1 \mathrm{ml}$ of $10^{9}$ bacterial inocula. These inoculated flasks were incubated at room temperature on an orbital shaker at $150 \mathrm{rpm}$. Uninoculated flasks (control) were also prepared to check the abiotic degradation under the same conditions. An aliquot of $5 \mathrm{~mL}$ sample was taken during 3 day intervals from each flask. Samples were centrifuged to remove suspended bacterial biomass and presence of endosulfan was examined using gas chromatography.

\section{Results and discussion}

2.1 Socio-economic and health impact survey: From the survey it was observed that $92 \%$ of the people in Wayand district depend up on farming for their livelihood. About $31 \%$ people are illiterate, $34 \%$ having middle school education 
and remaining has primary education. Most of the people have annually income according to their annual yield from their farm. $80 \%$ of people are fully depending on rain for their irrigation; Wayand district got an average rainfall of 25,00 millimeters per year. The major pesticides used in Wayanad ditricts are Ecalux (quinalphos), sevin, bavestin, emisan etc. mostly against the attack of Odoiporous longicollis (Pseudo stem weevil ), Cosmopolites sordidus (Rhizome weevil) and Spodoptera litura (Leaf eating caterpillars). But they use the pesticides without any gloves and also they didn't get any classes from Agriculture department for how to use pesticides, so they use pesticide according to the recommendations of shop keepers. All the farmers are opting branded pesticides only and also about $70 \%$ farmers are workers in their own farm. There is no mass fish kill report on their water resources.

The problem of pesticide exercise in farming is of particular importance as it has a significant negative impact on farmer's health (Antle et al. 1998; Ajayi 2000). In the present study $16 \%$ people suffer health problems during the application of pesticides such as head ache, burning effect, dinginess etc. $100 \%$ farmers adopt blanket spray for the application of pesticides. Many researchers reported the health problems during pesticide application such as headache, dizziness, muscular twitching, skin irritation and respiratory discomfort (Yassin et al. 2002; Maumbe and Swinton 2003; Mancini et al. 2005).

Pesticide not only affects human health, but also affects other environmental factors, for example soil, surface and ground water, crop productivity, microand macroflora and fauna, etc. (Pimentel 2005). Regardless of such environmental and health effects, farm workers in developing countries keep on to use pesticides in increasing quantities (Wilson, 2000; Wilson and Tisdell, 2001). Murphy et al. (1999) reported considerably more signs and symptoms in pesticide sprayers compared to the control people. Over half of the total respondents experienced skin irritations, more than a quarter experienced eye irritations and 7-12\% experienced stomach poisoning in Zimbabwe (Maumbe and Swinton 2003).

2.2 Physicochemical characteristics of soil: Various physico-chemical properties of the soil such as temperature, Moisture content, $\mathrm{pH}$, conductivity, organic carbon, organic matter has been studied and the results are presented in Table 1 and 2. Available nitrogen, available phosphorous and available potassium were also studied (Table 3). Soil temperature ranged between $20^{\circ} \mathrm{C}$ and $27^{\circ} \mathrm{C}$ during the study period and the maximum temperature of $27^{\circ} \mathrm{C}$ was recorded from Padinjarathara Banana field and the minimum of $20^{\circ} \mathrm{C}$ was recorded from Kottathara paddy field. The $\mathrm{pH}$ values ranged from 4.08 to 6.25 and the highest $\mathrm{pH}$ recorded from Kottathara Banana field and lowest $\mathrm{pH}$ recorded from Padinjarathara paddy field. Soil conductivity ranged between 0.07 and $1.22 \mathrm{mS}$ 
In the present study highest organic carbon of $1.714 \%$ recorded from Kottathara paddy field and lowest organic carbon of $0.852 \%$ from Padinjarathara and Kottathara Banana fields. Available nitrogen ranged from $378-1890 \mathrm{Kg} / \mathrm{ha}$. Highest available potassium of $5.510 \mathrm{~kg} / \mathrm{ha}$ was recorded from Kottathar paddy field and the least available potassium of $2.912 \mathrm{~kg} / \mathrm{ha}$ recorded from Padinjarathara banana. The highest value of available phosphorous of $14.55 \mathrm{~kg} / \mathrm{ha}$ recorded from Padinjarathara paddyfield and the least value $8.80 \mathrm{~kg} / \mathrm{ha}$ from Padinjarathara banana field. Highest organic matter of $2.95 \%$ recorded from Kottathara paddy field and lowest organic matter of $1.4 \%$ from Padinjarathara and Kottathara Banana fields.

Table No. 1 Physico-chemical characteristics of the soil

\begin{tabular}{ccccc}
\hline SamplingSites & $\begin{array}{c}\text { Soil } \\
\text { Temperature } \\
\left({ }^{\circ} \mathbf{C}\right)\end{array}$ & $\begin{array}{c}\text { Moisture } \\
\text { Content }(\%)\end{array}$ & $\mathbf{p H}$ & $\begin{array}{c}\text { Conductivity } \\
(\mathbf{m S})\end{array}$ \\
\hline KPF & 20 & 42 & 5.09 & 1.22 \\
PBF & 27 & 16.37 & 4.28 & 0.77 \\
PPF & 21 & 40 & 4.08 & 0.23 \\
KBF & 26 & 24.11 & 6.25 & 0.07 \\
\hline
\end{tabular}

Kottathara paddy field - KPF, Padinjarathara Banana field- PBF, Padinjarathara paddy field - PPF, Kottathara Banana field- KBF

Table No. 2 Soil organic carbon and organic matter content of the study area

\begin{tabular}{ccc}
\hline SamplingSites & Organic carbon (\%) & Organic matter (\%) \\
\hline KPF & 1.714 & 2.95 \\
PBF & 0.852 & 1.4 \\
PPF & 1.701 & 2.92 \\
KBF & 0.852 & 1.4 \\
\hline
\end{tabular}

Kottathara paddy field - KPF, Padinjarathara Banana field- PBF, Padinjarathara paddy field - PPF, Kottathara Banana field- KBF

Soils of selected study area are feebly acidic and the $\mathrm{pH}$ ranged from 4.08 to 6.25. Physicochemical characteristics of soil showed spatial variation. Spatial variations of soil characteristics are mainly due to the topography of the study area. A number of studies have exposed that even minute scale topographical landforms can change environmental conditions (Scowcroft et al. 2000). The same results were observed by different researchers; Miller et al. (1998) observed that organic carbon showed to vary with slope position and variation of soil properties within a distinct climatic area may also result from topographic heterogeneity (Brubaker et 
al. 1993). Another important reason for the spatial variation may be the vegetation cover. The difference in vegetation should affect the soil environment in many ways, including changing light intensity, wind, temperature, and soil moisture and nutrients; these should lead to remarkable changes in soil microbial diversity and structure (Greipsson 1995; Greipsson and El-Mayas 1999). In the present work vegetation differs considerably between the sampling locations because of samples were collected from different types of agriculture systems.

Table No. 3 Nutrient content of the soils

\begin{tabular}{cccc}
\hline $\begin{array}{c}\text { Sampling } \\
\text { sites }\end{array}$ & $\begin{array}{c}\text { Available } \\
\text { Nitrogen (Kg/ha) }\end{array}$ & $\begin{array}{c}\text { Available } \\
\text { Phosphorous (Kg/ha) }\end{array}$ & $\begin{array}{c}\text { Available } \\
\text { Potassium (Kg/ha) }\end{array}$ \\
\hline KPF & 1890 & 15.50 & 5.510 \\
PBF & 378 & 8.80 & 2.912 \\
KBF & 630 & 13.98 & 4.625 \\
PPF & 1764 & 14.55 & 4.816 \\
\hline
\end{tabular}

Kottathara paddy field - KPF, Padinjarathara Banana field- PBF, Padinjarathara paddy field - PPF, Kottathara Banana field- KBF

2.3 Load of Total heterotrophic bacteria: In the present study total heterotrophic bacterial (THB) load ranged from $32 \times 10^{5}$ to $260 \times 10^{5} \mathrm{CFU} / \mathrm{g}$; highest count recorded from Kottathara paddy field and the lowest count recorded from Kottathara banana field (Table No.4). Spatial variation of the microbial load attribute to variation of the soil characteristics and vegetation structure due to the difference in terrine of the study area. A number of studies have shown that even small scale topographical landforms can alter environmental conditions, which in turn retard or accelerate the activity of organisms (Scowcroft et al. 2000). The effects of topographical landforms on species composition, productivity, environmental conditions, and soil characteristics have been well investigated (Barnes et al. 1998).

Table No. 4 Load of total heterotrophic bacteria (THB) in the soils of selected study area

\begin{tabular}{cc}
\hline Sampling sites & THB Count (CFU/g) \\
\hline KBF & $32 \times 10^{5}$ \\
KPF & $300 \times 10^{5}$ \\
PBF & $76 \times 10^{5}$ \\
PPF & $270 \times 10^{5}$ \\
\hline
\end{tabular}

Kottathara paddy field - KPF, Padinjarathara Banana field- PBF, Padinjarathara paddy field - PPF,Kottathara Banana field- KBF 
2.4 Pesticide residues in the soil: 28 pesticide compounds in the soil samples were analyzed and the results revealed that there were no pesticide residues in the soils. Fate of pesticides in soil is controlled by chemical, biological and physical dynamics of this matrix (Sparks 2003). Above processes can be grouped into those that affect persistence, including chemical and microbial degradation, and those that affect mobility, involving sorption, plant uptake, volatilization, wind erosion, run-off and leaching (Andreu and Pico 2004). Chemical degradation occurs during process such as photolysis, hydrolysis, oxidation and reduction (Bavcon et al. 2002). Biological degradation takes place when soil microorganisms consume or break down pesticides (Sassman et al. 2004).

One thing that has been shown to boost the rate of microbial degradation of pesticides in soil is one or more previous applications of the same pesticide or another pesticide with a similar chemical structure. This phenomenon is known as accelerated or enhanced degradation (Racke 1990). In the present study we noted high number of pesticide resistant bacteria in the soils of selected study area that may be the major reason for the absence of pesticide residues. Wayand district got average rainfall of 25,00 millimeters per year, these also leads high run-off and leaching of pesticides. Chemical degradation and the other factors like plant uptake, volatilization and wind erosion studies etc. are needed to finalise the fate of pesticide in the selected study area.

2.5 Bacterial Endosulfan resistance: A total of 9 bacterial strains were (with $50 \mu \mathrm{g} / \mathrm{ml}$ of endosulfan in isolating media) isolated from the soils of banana and paddy fields of selected study area. The results revealed that most of the bacterial strains were resistant to endosulfan. Out of the 9 strains isolated 6 were highly resistant to endosulfan $(500-700 \mu \mathrm{g} / \mathrm{ml})$ and the other 3 isolates showed the resistance of $250-500 \mu \mathrm{g} / \mathrm{ml}$ (Table 1). Findings of the present study are almost similar to those reported by Sahin et al. (2003), reported that many bacterial strains

Table No. 5 Endosulfan resistance patterns of bacterial strains

\begin{tabular}{cc}
\hline Isolates & MIC to Endosulfan $(\boldsymbol{\mu g} / \mathbf{m l})$ \\
\hline 1 & $500-700$ \\
2 & $500-700$ \\
3 & $250-500$ \\
4 & $500-700$ \\
5 & $500-700$ \\
6 & $250-500$ \\
7 & $500-700$ \\
8 & $250-500$ \\
9 & $500-700$ \\
\hline
\end{tabular}


tolerated concentrations up to $800 \mu \mathrm{g}$ of endosulfan $/ \mathrm{ml}$. Findings are almost similar to those reported by Ferrer et al. (1986), reported that 100, 200, 300, 400 and 500 $\mu \mathrm{g} / \mathrm{ml}$ of 2,3,6-TBA (2,3,6- trichlorobenzoic acid) caused 28.0, 47.8, 54.5, 61.2 and $95.6 \%$ inhibition respectively. The elevated levels of resistance was originate among the isolates is probably attributed to the endosulfan usage in the study area in the past or present time.

2.6 Bioremediation of Endosulfan: Biodegradation of persistent compounds is an important mechanism for their dissemination in the environment (Marcae 1990). In predicting the persistence of synthetic chemicals in soil, sediment and natural water, it is necessary to determine the role of endogenous microorganisms in the overall degradation process. In the present study, isolate 9 demonstrating prolific growth and high resistance was selected to check their capability to degrade endosulfan over time. Identification of the selected strain reveals that it belongs to the genus Bacillus. Results of endosulfan removal studies showed that with increase in time, the biomass of the bacterial strains increased. The complete disappearance of endosulfan from the spiked and inoculated broth during the $3^{\text {rd }}$ day of incubation was observed. While the control flask showed the presence of endosulfan during the experimental period. Bacteria and fungi, which degrade endosulfan isomers in liquid culture have been isolated and characterized in many laboratories (Kullman and Matsumura 1996; Awasthi et al. 1997). Endosulfan diol, endosulfan sulfate, endosulfan aldehyde, endosulfan ether and endosulfan lactone have been demonstrated as the major metabolites formed during its degradation.

\section{Conclusion}

Pesticide resistant bacteria are widely distributed in the soils of selected study area and the tolerance varied between bacteria even though they were isolated from the soils of the same area. The selected Bacillus species carry the ability to degrade endosulfan at accelerated rates and it could be useful in framing a bioremediation strategy for pesticide contaminated soil and water environments. The use of microorganism for bioremediation requires better and more understanding of all the physiological and biochemical aspects involved in chemical transformations of the pesticide. Thus further studies are needed prior to start any applied bioremediation process using the isolate. 


\section{References}

Ajayi, O.C., Camara, M., Fleischer, G., Haidara, F., Sow, M., Traore, A., Van Der Valk, H. (2002). Socio-economic assessment of pesticide use in Mali. Pesticide Policy Project [Special Issue]. Publication series no. 6. Germany: University of Hanover.

Andreu, V., Pico, Y. (2004). Determination of pesticides and their degradation products in soil: critical review and comparison of methods. Trends in Analytical Chemistry, 23, 10-11.

Antle, J.M., Pingali, P.L. (1995). Pesticides, productivity, and farmer health: a Philippine case study. In P. L. Pingali, \& P. A. Roger (Eds.), Impact of pesticides on farmer health and the rice environment. Philippines: International Rice Research Institute. 361-385.

Awasthi, N., Manickam, N., Kumar, A. (1997). Biodegradation of endosulfan by a bacterial coculture. Bulletin of Environmental Contamination and Toxicology, 59, 928-934.

Barnes, B.V., Zak, D.R., Denton, S.R., Spurr, S.H. (1998). (eds.). Forest Ecology. Fourth ed., New York. (pp 74) Wiley.

Bavcon, M., Trebse, P., Zupancic-Kralj, L. (2002). Investigations of the determination and transformations of diazinon and malathion under environmental conditions using gas chromatography coupled with a flame ionization detector. Chemosphere, 50, 595601.

Brubaker, S.C., Jones, A.J., Lewis, D.T., Frank, K. (1993). Soil properties associated with landscape position. Soil Science Society of America Journal, 57, 235-239.

Ferrer, M.R., Gonzalez-Lopez, J., Ramos-Cormenzana, A. (1986). Effect of some herbicides on the biological activity of Azotobacter vinelandii. Soil Biology and Biochemistry, 18, 237-238.

Greipsson, S., El-Mayas, H. (1999). Large-scale reclamation of barren lands in Iceland by aerial seeding. Land Degradation and Development,10,185 -193.

Greipsson, S. (1995). Effect of iron plaque on roots of rice on growth of plants in excess zinc and accumulation of phosphorus in plants in excess copper and nickel. Journal of Plant Nutrition, 18, $1659-1665$.

Holt, J.G., Kreig, N.R., Sneath, P.H.A., Staley, J.T., Williams, S.T. (1994). Bergey's Manual of Determinative Bacteriology, 9th edn. Baltimore, Maryland 21202, USA: Williams and Wilkins.

Hussain, S., Arsad, M., Saleem, M., Kalid, A. (2007). Biodegradation of alpha and beta endosulfan by soil bacteria. Biodegradation, 1, 120-138.

Jackson, M.H. (1973). Soil chemical analysis .Prentice hall of India (Pvt Ltd), New Delhi, India.

Kathpal, T.S., Singh, A., Dhankhar, J.S., Singh, G. (1997). Fate of endosulfan in cotton soil under sub-tropical conditions of Northern India. Pesticide Science, 50, 21-27.

Keith, L.H., Telliard, W.A. (1979). Priority pollutants I: A perspective view. Environmental Science and Technology, 13, 416-423.

Kullman, S.W., Matsumura, F. (1996). Metabolic pathway utilized by Phanerochaete chrysosporium for degradation of the cyclodiene pesticide endosulfan. Applied and Environmental Microbiology, 62, 593-600. 
Lakshmi, C.V., Kumar, M., Khanna, S. (2009). Biodegradation of Chlorpyrifos in Soil by Enriched Cultures. Current Microbiology, 58, 35-38.

Lui, G.W., Talnagi, J.W., Strohl, W.R., Pfister, R.M. (1983). Hexavalent chromium resistant bacteria isolated from river sediments. Applied Environmental Microbiology, 46, 846-854.

Macrae, I.C. (1990). The microbial Degradation of pesticides and related compounds. Residue Reviews, 88, 187.

Mancini, F., Van Bruggen, A.H.C., Jiggins, J.L.S., Ambatipudi, A.C., Murphy, H. (2005). Acute pesticide poisoning among female and male cotton growers in India. International Journal of Occupational and Environmental Health, 11, 221-232.

Maumbe, B.M., Swinton, S.M. (2003). Hidden health costs of pesticide use in Zimbabwe's smallholder cotton growers. Social Science \& Medicine, 57, 1559-1571.

Morgan, M.F. (1945). Chemical diagnoses by the universal soil testing system. Connectieut agricultural experiment station, SA, 450.

Murphy, H.H., Sanusi, A., Dilts, R., Djajadisastra, M., Hirschhorn, N., Yuliantiningsih, S. (1999). Health effects of pesticide use among Indonesian women farmers: part I: exposure and acute health effects. Journal of Agromedicine, 6, 61-85.

Pimentel, D. (2005). Environmental and economic costs of the application of pesticides primarily in the United States. Environment, Development and Sustainability. 7, 229252.

Racke, K.D., (1990). Pesticides in the soil microbial ecosystem. Enhanced biodegradation of pesticides in the environment. In: Racke, K.D., Coats, J.R. (Eds.), Enhanced Biodegradation of Pesticides in the Environment. American Chemical Society, Washington, DC, 1-12.

Rao, D.M.R., Murty, A.S. (1980). Persistence of endosulfan in soils. Journal of Agricultural and Food Chemistry, 28, 1099-1101.

Sassman, S.A., Lee, L.S., Bischoff, M., Turco, R.F., 2004. Assessing N,N'-dibutylurea $(D B U)$ formation in soils after application of $n$-butylisocyanate and benlate fungicides. Journal of Agricultural and Food Chemistry, 52, 747.

Scowcroft, P.G., Turner, D.R., Vitousek, P.M. (2006). Decomposition of Metrosideros polymorpha leaf litter along elevational gradients in Hawaii. Global Change Biology, 6, 73-85.

Singh, K., Brajesh, K., Walker, A., Alum, J., Morgan, W., Wright, D.J., 2004. Biodegradation of chlorpyrifos by Enterobacter strain B-14 and its use in biodegradation of contaminated soils. Applied Environmental Microbiology, 70, 4855-4863.

Sparks, R. (2003). Environmental Soil Chemistry, Elsevier, Amsterdam, The Netherlands.

Stewart, D.K.R., Cairns, K.G. (1974). Endosulfan persistence in soil and uptake by potato tubers. Journal of Agricultural and Food Chemistry, 22, 984-986.

Sunderam, R.I.M., Cheng, D.M.H. (1992). Toxicity of endosulfan to native and introduced fish in Australia. Environmental Toxicology \& Chemistry, 11, 1469-1476.

Verschueren, K. (1983). Endosulfan. In: Handbook of Environmental Data on Organic Chemicals. Van Nostrand Reinhold, New York, 604-607. 
Wilson, C., Tisdell, C. (2001). Why farmers continue to use pesticides despite environmental, health and sustainability costs. Ecological Economics, 39, 449-462.

Wilson, C. (2000). Environmental and human costs of commercial agricultural production in south Asia. International Journal of Social Economics, 27, 816-846.

Yassin, M.M., Abu Mourad, T.A., Safi, J.M. (2002). Knowledge, attitude, practice, and toxicity symptoms associated with pesticide use among farm workers in the Gaza Strip. Occupational and Environmental Medicine, 59, 387-394. 